\title{
Peripheral lymphocyte subsets in chronic hepatitis C: Effects of 12 weeks of antiviral treatment with interferon-alpha plus ribavirin
}

\author{
Isabela S. Oliveira ${ }^{a}$, Lucas P. Carvalho ${ }^{b}$, Maria Isabel Schinoni ${ }^{c}$, Raymundo Paraná ${ }^{c}$, \\ Ajax M. Atta d, Maria Luiza B. Sousa Atta ${ }^{d, *}$ \\ a Programa de Pós-Graduação em Imunologia, Universidade Federal da Bahia, Salvador, BA, Brazil \\ ${ }^{\mathrm{b}}$ Serviço de Imunologia, Hospital Universitário Professor Edgard Santos, Universidade Federal da Bahia, Salvador, BA, Brazil \\ ' Serviço de Gastro-Hepatologia, Hospital Universitário Professor Edgard Santos, Universidade Federal da Bahia, Salvador, BA, Brazil \\ d Departamento de Análises Clínicas e Toxicológicas, Faculdade de Farmácia, Universidade Federal da Bahia, 40170115, Rua Barão de Jeremoabo s/n, \\ Salvador, BA, Brazil
}

\section{A R T I C L E I N F O}

\section{Article history:}

Received 25 July 2015

Received in revised form 4 November 2015

Accepted 17 December 2015

Available online 21 December 2015

\begin{abstract}
A B S T R A C T
Chronic infection with hepatitis $\mathrm{C}$ virus (HCV) causes a quantitative and functional alteration in innate and adaptative immunity. In the present work, we determined by flow-cytometry the profile of blood lymphocyte of untreated HCV patients and in subjects of this group that achieved or not an early virologic response at 12 -weeks of treatment with interferon- $\alpha$ plus ribavirin. Twenty-six untreated HCV patients and 20 control healthy individuals were enrolled in the study. Untreated HCV patients had a higher proportion of $\mathrm{B}$ cell and a lower proportion of $\mathrm{CD}^{+} \mathrm{T}$ cell and NK cells than healthy individuals did, but the proportions of $\mathrm{CD}^{+}$T cells and Treg cells $\left(\mathrm{CD} 4^{+} \mathrm{CD}_{2} 5^{+} \mathrm{Foxp}^{+}\right)$were similar in these patients and controls. Untreated HCV patients presenting cryoglobulinemia had a lower proportion of Treg cells and a lower Treg/NK cell ratio when compared with those without cryoglobulins. Nineteen out of 26 untreated HCV patients remained in the study and were treated with Interferon- $\alpha$ plus ribavirin. At 12weeks of treatment, 10 of them achieved early virologic response (EVR), whereas 9 were non-responders (NR). EVR patients differed from NR patients in the increase of their proportion of NK cells at 12 weeks of treatment. In conclusion, untreated HCV patients exhibit an altered profile of blood lymphocyte subsets, including a reduction in the proportion of $\mathrm{CD} 4{ }^{+} \mathrm{CD} 25^{+} \mathrm{FoxP} 3^{+} \mathrm{T}$ regulatory cells in patients that present cryoglobulinemia. An early virological response at 12 -weeks of treatment with IFN- $\alpha$ plus ribavirin seems to be associated a significant improvement in the proportion of NK cells of HCV treated patients.
\end{abstract}

(c) 2015 Elsevier Ltd. All rights reserved.

\section{Introduction}

Chronic hepatitis $\mathrm{C}(\mathrm{CHC})$ is an important public health problem. According to the World Health Organization (WHO), more than 170 million people are infected worldwide, with limited therapeutic options and without a preventive vaccine [1-3].

The hepatitis $C$ virus causes persistent infection in most infected individuals; however, the mechanisms involved in this chronic infection still need better knowledge. Factors as HCV mutation, inefficient antigen presentation, impaired NK cell function, T cell depletion and immune suppression mediated by regulatory $\mathrm{T}$ cells could contribute to the chronic HCV infection [4-7].

Chronic hepatitis $\mathrm{C}$ has been associated with autoimmune

\footnotetext{
* Corresponding author.
}

manifestations, mainly the production of cryoglobulins (cryoprecipitable immune complexes formed by HCV core antigen, core antibodies, and complement $\mathrm{C1q}$ ) and the production of HCV antibodies that cross-react with self-antigens as non-organ-specific autoantibodies (NOSA) [8,9]. The involvement of regulatory T cells in chronic HCV infection has been reported in some studies, where a decrease in the number of blood Treg cells has been associated with the autoimmune findings found in HCV patients. Other studies have reported an increased proportion of peripheral Treg cell phenotypes represented by $\mathrm{CD} 4^{+} \mathrm{CD} 25^{+ \text {high }}$ and $\mathrm{CD} 25^{+} \mathrm{FoxP}^{+}$in $\mathrm{HCV}$ patients, which could down-regulate the anti-HCV immune response of T lymphocytes [10-14].

In previous studies, we have showed a high prevalence of autoimmune findings in Brazilian HCV patients, mainly represented by cryoglobulinemia and significant production of NOSA [15-18]. However, the profile of peripheral lymphocyte subsets 
involved with either the innate or adaptive immune response of these individuals against HCV and self-antigens still need to be better investigated, justifying the present study. In addition, we also investigated how antiviral treatment with IFN- $\alpha$ plus ribavirin could influence the profile of these immune cells in treated patients that achieved an early virologic response or were non-responders at 12 -weeks of this treatment.

\section{Material and methods}

\subsection{Patients and controls}

In this study were consecutively enrolled $26 \mathrm{HCV}$ patients from both genders ( 12 men and 14 women), with age ranging from 33 to 65 years, without previous antiviral therapy. The clinical evaluation determined the presence of chronic hepatitis $C$ in these individuals, supported by laboratory tests for aminotransferases and HCVantibodies, the demonstration of blood HCV-RNA, HCV-genotyping, and liver histology (necroinflammatory activity and fibrosis) [19]. Two patients were evaluated with the Fibroscan ${ }^{\circledR}$ to avoid the risk of bleeding due to liver biopsy (Table 1 ).

Blood samples of these individuals were collected before and at 12 weeks of antiviral treatment with IFN- $\alpha$ plus ribavirin, when the virological response was evaluated, using the Brazilian Clinical Protocol and Therapeutic Guidelines for Viral Hepatitis $C$ and Coinfections [20]. In this way, early virological response (EVR) was defined as a drop of 2 Log in the blood HCV load or a blood HCV load of less than $1 / 100$ of the previous HCV-RNA load. A total early virological response corresponded to the absence of blood HCVRNA at 12-week treatment. The control group was formed by 20 healthy individuals ( 10 men and 10 women, with a mean age of $48.7 \pm 6.7$ years). All tested seronegative for viral hepatitis (A, B and C), HIV, and HTLV infection. The Ethical Committee of the Professor Edgard Santos Hospital (Bahia Federal University) approved the study.

\subsection{Cryoglobulin and NOSA}

The presence of cryoglobulinemia was tested by both cryoprecipitate and gel-diffusion [21]. Serum rheumatoid factor (RF)

Table 1

Demographic and clinical findings in 26 patients with chronic hepatitis $\mathrm{C}(\mathrm{CHC})$ before antiviral treatment with Interferon- $\alpha$ plus ribavirin (T0).

\begin{tabular}{|c|c|c|}
\hline Characteristic & $\mathrm{CHC}-\mathrm{TO}$ n 26 & (\%) \\
\hline \multicolumn{3}{|l|}{ Gender } \\
\hline Man (age $50.2 \pm 9.2$ years) & 12 & 46 \\
\hline Woman (Age $50.5 \pm 7.3$ years) & 14 & 54 \\
\hline \multicolumn{3}{|l|}{ Genotype } \\
\hline 1 & 17 & 65 \\
\hline 2 & 2 & 7 \\
\hline 3 & 7 & 27 \\
\hline \multicolumn{3}{|l|}{ Necroinflammatory activity } \\
\hline 0 & 7 & 27 \\
\hline 1 & 8 & 31 \\
\hline 2 & 7 & 27 \\
\hline 3 & 1 & 3 \\
\hline Not evaluated & 3 & 12 \\
\hline \multicolumn{3}{|l|}{ Fibrosis } \\
\hline 1 & 4 & 16 \\
\hline 2 & 15 & 58 \\
\hline 3 & 2 & 8 \\
\hline 4 & 2 & 8 \\
\hline Not evaluated & 3 & 12 \\
\hline \multicolumn{3}{|l|}{ Viral load } \\
\hline Low $(<600.000 \mathrm{IU} / \mathrm{mL})$ & 9 & 35 \\
\hline $\operatorname{High}(\geq 600.000 \mathrm{IU} / \mathrm{mL})$ & 17 & 65 \\
\hline
\end{tabular}

was probed by nephelometry, using the IMMAGE System from Beckman Coulter (USA). In this immunoassay, a positive RF titer was $>20 \mathrm{IU} / \mathrm{ml}$. Antinuclear autoantibodies (ANA) were detected by the indirect fluorescent antibody test (IFAT) using HEp-2 cell antigen substrate (VIRO-IMMUN Labor-Diagnostika GmbH, Germany). Smooth muscle and LKM-1 autoantibodies were tested using a commercial IFAT with combined tissue sections of a stomach, kidney, and rat liver from the same source. The cut-off in these immune reactions was a positive test with serum diluted at 1:40.

\subsection{Blood lymphocytes}

Lymphocyte subsets were identified and quantified in the patients' peripheral blood by flow cytometry. The following immune reactants were used in these assays: anti-CD3 phycoerythrin (PE), anti-CD4-fluorescein isothiocyanate (FITC), anti-CD8 peridinin chlorophyll protein (PerCP)-Cy5, anti-CD19-PE, CD56allophycocyanin (APC) (eBioscience San Diego, CA, USA). The cells were acquired using an FACSCanto II cytometer (BD Biosciences, USA). The phenotypic identification of blood Treg cells was determined using the following immune reactants: anti-CD4-FITC, antiCD25-APC, and anti-FoxP3-PE (Human/Non-Human Primate Regulatory $\mathrm{T}$ Cell Staining Kit, eBioscences). Flow cytometry determined the absolute counts of this T cell subset with the cytometer above. Around $20,000 \mathrm{CD} 4^{+} \mathrm{T}$ cells were acquired to determine the frequency of regulatory T cells. The FlowJo software (Tree Star) was used in the cytometric analyzes of the lymphocyte subsets (Fig. 1).

\subsection{Statistical analysis}

Statistical analysis was performed using the Prism software version 6.0 (GraphPad Software Inc., USA). The continuous variables were expressed as mean \pm standard deviation (SD) or median and interquartile range (IQR), in accordance with their distribution in the normality test of D'Agostino and Pearson. The correlation test of Pearson or Spearman was used as required in each situation. The unpaired t-test of Student compared the means of two independent groups, whereas the U test of Mann-Whitney compared the medians. Paired groups were analyzed with the paired t-test of Student or the test of Wilcoxon in accordance with their variable distributions. A $p$ value $<0.05$ was considered significant.

\section{Results}

\subsection{Clinical, virological, and demographic findings in untreated HCV patients}

Most untreated patients enrolled in this study were infected with HCV-genotype 1, followed by the infection with the HCVgenotype 3 , being less frequent the infection with the HCVgenotype 2. A high blood HCV load (>600,000 IU/mL) was detected in the majority of the patients before treatment. Twenty-two subjects had ALT levels above the reference value of $41 \mathrm{U} / \mathrm{L}$, varying from 43 to $459 \mathrm{U} / \mathrm{L}$. Mild to moderate necroinflammatory activity, as well as mild to moderate fibrosis, was prevalent in this group.

Around 17 (65\%) of the 26 untreated HCV patients were positive for at least one autoimmune marker; 13 of them had cryoglobulinemia, whereas 11 exhibited NOSA. Rheumatoid factor was found in 5 out of 26 subjects, antinuclear antibodies were detected in 5 , and $9(35 \%)$ untreated patients were positive for smooth muscle antibodies. 

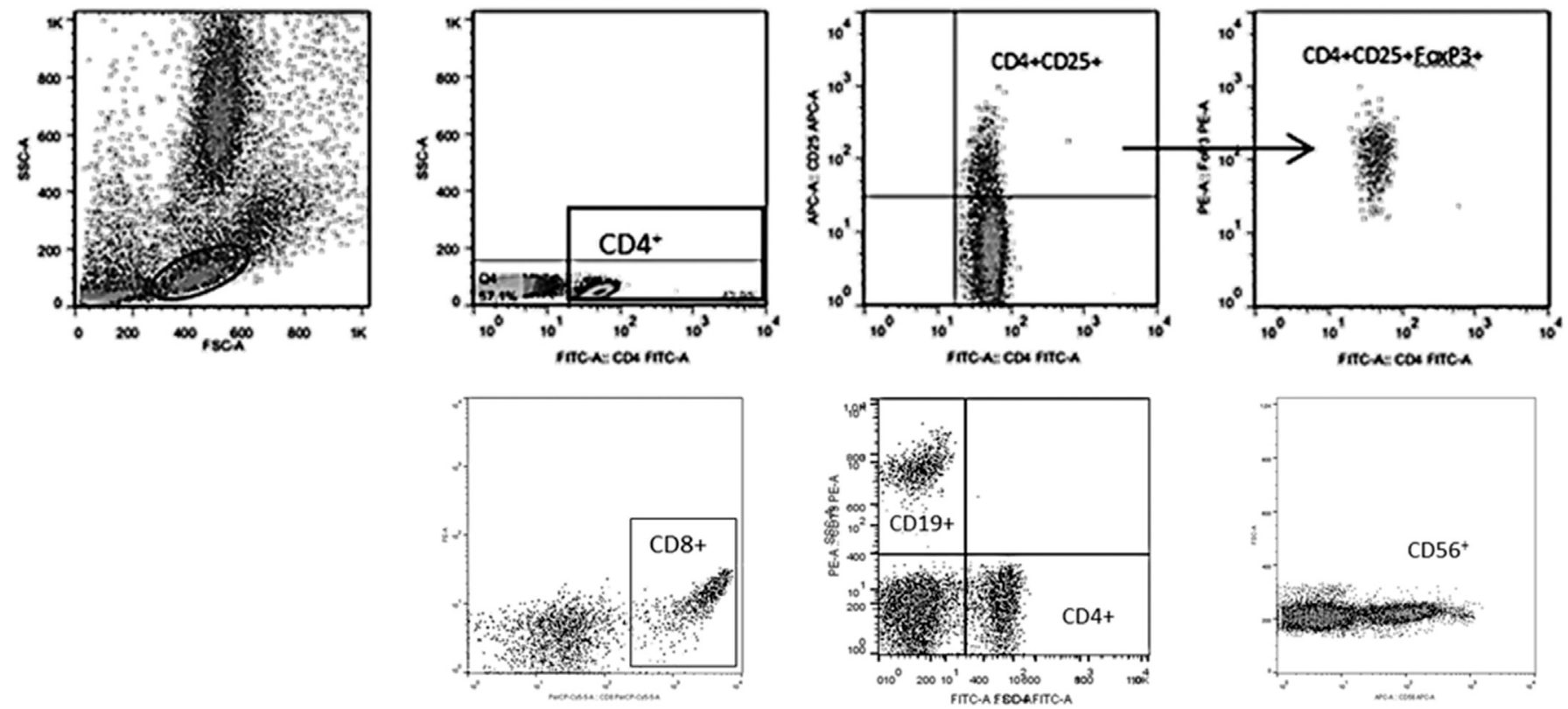

Fig. 1. Flow cytometry analysis of peripheral blood lymphocyte subsets performed in chronic hepatitis $\mathrm{C}$ patients and healthy individuals.

\subsection{Viral response at 12 -weeks of treatment with IFN- $\alpha$ plus ribavirin}

Twenty-three out of 26 untreated patients started antiviral treatment of IFN- $\alpha$ plus ribavirin, but 4 of them abandoned the study. Thus, only 19 patients completed 12-weeks of treatment and were monitored for their infection status at this time. Ten out of these 19 treated HCV patients presented an early virologic response: 2 were blood HCV-RNA negative, whereas 8 exhibited a significant drop in their previous HCV load. In contrast, 9 patients of 19 treated patients did not respond to the antiviral treatment and were classified as non-responders (NR). The viral load of HCV before treatment was higher in NR patients. The ALT levels were similar in NR and EVR patients, and no prevalence of HCV genotype 1 was observed in non-responders patients (Table 2).

\subsection{Lymphocyte subsets in untreated HCV patients}

The proportions of B cells $\left(\mathrm{CD} 19^{+}\right), \mathrm{CD}^{+} \mathrm{T}$ cells, and NK cells were different, comparing healthy controls and untreated HCV patients. There was an increase in the proportion of B cells in the patients $(p=0.042)$. However, they had a lower proportion of both $\mathrm{CD}^{+} \mathrm{T}$ cells and NK cells than controls $(p=0.048$ and $p=0.028$, respectively). Nonetheless, their proportions of $\mathrm{CD}^{+}{ }^{+} \mathrm{T}$ cells and $\mathrm{CD} 4{ }^{+} \mathrm{CD} 25^{+} \mathrm{FoxP}^{+}$Treg cells were similar to those from the controls ( $p=0.513$ and $p=0.309$, respectively) (Fig. 2).

The proportion of $\mathrm{CD}^{+}{ }^{+} \mathrm{CD} 25^{+} \mathrm{FoxP} 3^{+}$Treg cells in $\mathrm{HCV}$ patients

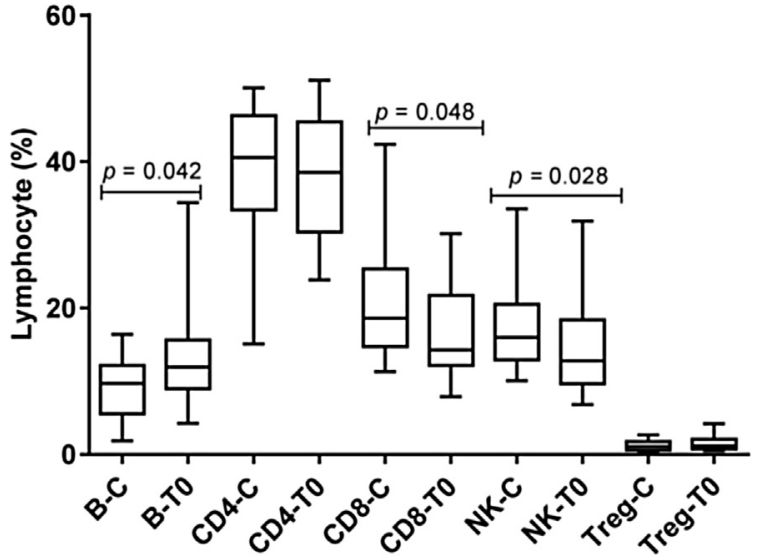

Fig. 2. Proportion of blood lymphocytes subtypes in 20 control healthy individuals (BC, CD4-C, CD8-C, NK-C, Treg-C) and in 26 untreated HCV patients (B-T0, CD4-T0, CD8T0, NK-T0 and Treg-T0). Box and whiskers represent the median, interquartile range $(25 \%-75 \%)$ and maximum and minimum. $\left(\mathrm{B}=\mathrm{B}\right.$ cell, $\mathrm{CD} 4=\mathrm{CD} 4^{+} \mathrm{T}$ cell, $\mathrm{CD} 8=\mathrm{CD}^{+} \mathrm{T}$ cell, NK $=$ NK cell and Treg $=\mathrm{CD} 4^{+} \mathrm{CD} 25^{+} \mathrm{FoxP}^{+}$Treg cell).

was not affected by their viral load of HCV, but it was lower in patients with cryoglobulinemia in comparison to that exhibited by patients without cryoglobulins (mean $1.13 \pm 0.64 \%$ against $1.90 \pm 1.06 \%, p=0.038$ ) (Fig. 3). However, the proportion of these cells was similar in patients with or without NOSA $(p=0.181)$. The

Table 2

Laboratory findings in 19 patients with chronic hepatitis $\mathrm{C}(\mathrm{CHC})$ before (T0) and after 12-weeks treatment (T12).

\begin{tabular}{|c|c|c|c|}
\hline & CHC-T0 & CHC-T12 & $p$-value \\
\hline $\mathrm{VL}\left(\log _{10}\right)^{\mathrm{a}}$ & $5.76 \pm 0.67(4.56-6.94)$ & $3.85(0-6.16)(0-6.74)$ & 0.001 \\
\hline $\operatorname{ALT}(\mathrm{U} / \mathrm{L})^{\mathrm{a}}$ & $53(43-122)(20-459)$ & $39.3 \pm 21.4(11-91)$ & 0.001 \\
\hline Leukocytes $^{\mathrm{a}}$ (cells/mm³) & $5.315 \pm 1.515(2.280-8.840)$ & $3.075(2.350-4.330)(1.930-15.050)$ & 0.005 \\
\hline Hemoglobin $^{\mathrm{a}}(\mathrm{g} / \mathrm{dL})$ & $13.6(12.9-14.3)(4.8-16.9)$ & $11.7 \pm 1.3(9.4-14.9)$ & 0.005 \\
\hline Platelets ${ }^{\mathrm{b}}\left(\right.$ cells $\left./ \mathrm{mm}^{3}\right)$ & $189.6 \pm 59.2(67-286)$ & $146.3 \pm 52.8(46-236)$ & $<0.001$ \\
\hline
\end{tabular}

VL: viral load; ALT: alanine aminotransferase.

a Wilcoxon test, median and IQR $(25 \%-75 \%)$.

b Paired t-test, mean \pm SD. 


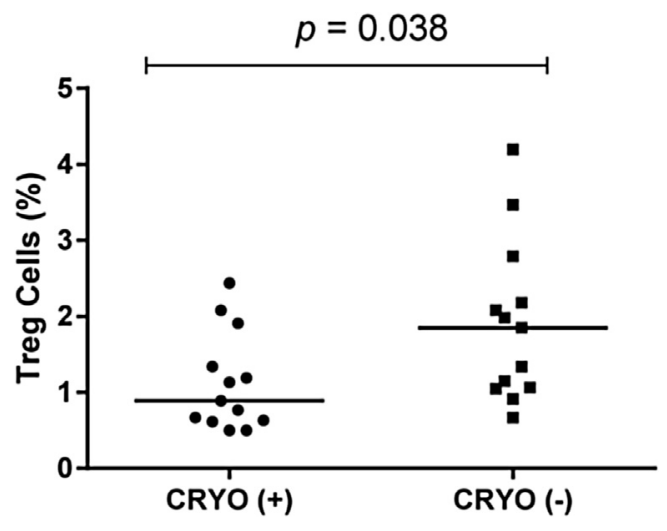

Fig. 3. Frequency of Treg cells $\left(\mathrm{CD} 4^{+} \mathrm{CD} 25^{+} \mathrm{FoxP}_{3}^{+}\right)$in the peripheral blood of chronic hepatitis $C$ patients having cryoglobulinemia (Positive, $n=13$ ) and without this cryoprecipitate (Negative, $n=13$ ), before treatment. Horizontal bars represent the means.

ratio of Treg cell/NK cell was higher in untreated HCV patients in comparison with that from healthy individuals. In addition, it was higher in untreated patients without cryoglobulins $(p=0.039)$ (Figs. 4 and 5).

\subsection{Lymphocyte subsets in treated HCV patients}

At week 12 of antiviral therapy, the proportions of B cells, $\mathrm{CD} 4^{+} \mathrm{T}$ cells, CD8 ${ }^{+} \mathrm{T}$ cells, and Treg cells in patients that had achieved an early virologic response (EVR) or were not responders (NR) were similar to those presented by these individuals before the antiviral treatment (T0). However, there was an increase in the proportion of NK cells in EVR patients when this subset of lymphocytes was compared with that presented by these subjects before antiviral therapy $(p=0.024)$ (Fig. 6).

\section{Discussion}

The present study evaluated the profile of different subsets of peripheral lymphocytes of patients chronically infected with HCV, before and at week 12 of treatment with interferon- $\alpha$ plus ribavirin. Chronic hepatitis $C$ caused an increase in the proportion of $B$ cells in untreated patients, which could represent the proliferative effect of HCV on these cells $[4,22,23]$. On the other hand, the increase in B cell proportion in the patients could be associated with the production of NOSA and anti-HCV antibodies. Additionally, there is an increase in BAFF production during chronic HCV infection [16,24]. Nonetheless, the proportion of B cells was similar in 12-week

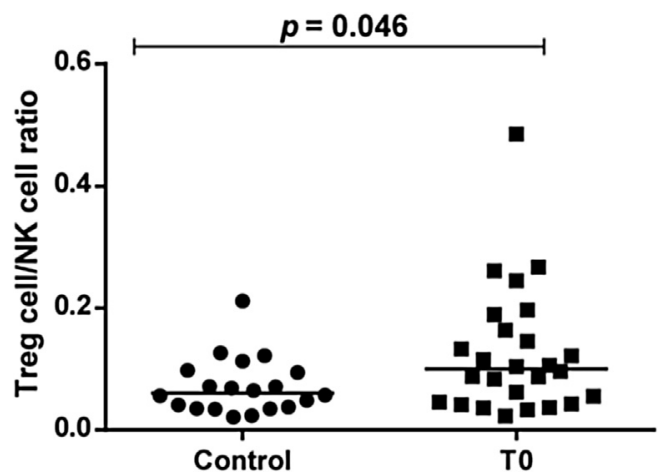

Fig. 4. Treg/NK cell ratio in 20 control healthy individuals and 26 untreated hepatitis $C$ patients before treatment (T0). Horizontal lines represent the medians.

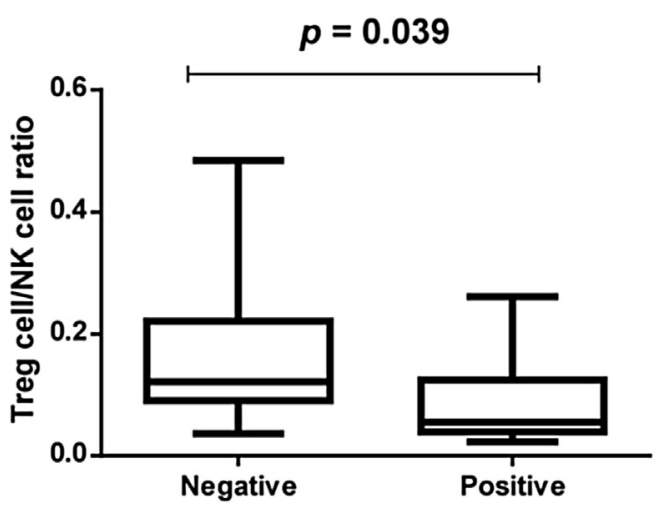

Fig. 5. Treg/NK cell ratio in untreated HCV patients that were negative $(n=13)$ or positive $(n=13)$ for the presence of cryoglobulinemia.

treated patients and controls, a finding that could be associated with the decrease in HCV antigen burden.

In our study, NK cell proportion was lower in untreated HCV patients in comparison with those from healthy controls. This finding has been confirmed in some studies, reporting low NK cell proportion and altered NK functions in chronic HCV infection [25-27]. The interaction CD81/HCV glycoprotein E2 on NK cells blocks NK cell activation, cytokine production, cytotoxic granule release, and proliferation [28,29]. Here, NK cell counts were normalized in EVR treated patients, associating this finding with the drop in HCV load caused by the IFN- $\alpha$ treatment. Nevertheless, the increase in NK cell proportion could be also associated with the acquisition of an NK activated cell phenotype following treatment with IFN- $\alpha$ [30]. Interestingly, we verified that the Treg/NK cell ratio was higher in untreated HCV patients, suggesting a negative control of Treg cell on the NK cell activation during HCV chronic infection, which could be down-modulated by the antiviral treatment with IFN- $\alpha /$ ribavirin.

Differently, $\mathrm{CD} 4^{+} \mathrm{T}$ cell proportion was similar to that from healthy controls in agreement with previous reports. The $\mathrm{CD} 4^{+} \mathrm{T}$ lymphocyte subset is necessary for the initiation and maintenance of the adaptative immune response against HCV of both B cell and $\mathrm{CD}^{+} \mathrm{T}$ cell to resolve the acute viral infection. Nevertheless, such importance of $\mathrm{HCV}$-specific $\mathrm{CD} 4^{+} \mathrm{T}$ cell is apparently lost during the chronic infection, which can be demonstrated by decreased IL-2 secretion and a lack of proliferative capacity [31-33].

The proportion of $\mathrm{CD} 4^{+} \mathrm{CD} 25^{+}$FoxP3 ${ }^{+}$Treg cells was not affected by the HCV load, as well as not being lower in untreated patients that were seropositive for NOSA or influenced by the antiviral treatment. However, the proportion of these cells was lower in patients with cryoglobulinemia. Such result suggested that these cells could exert an adverse immune regulation in the formation of this immune complex formed by antibodies against HCV core, IgM anti-IgG antibodies, and complement C1q, which is less efficient in cryoglobulinemia patients. Several studies have reported an increased proportion of regulatory $\mathrm{T}$ cells in patients chronically infected with HCV, which can be demonstrated in both liver and peripheral blood. However, other groups, confirming our results, have not found such findings [11-14].

In this work, the proportion of $\mathrm{CD}^{+} \mathrm{T}$ cells was lower in untreated HCV patients than in the controls. However, the percentage of these cells in EVR- and NR-treated patients was similar, suggesting a slow restoration of this lymphocyte subset after antiviral treatment. In chronic $\mathrm{HCV}$ infection, the $\mathrm{CD}^{+} \mathrm{T}$ cell immune response is weak or absent, presenting reduced cytotoxicity, insufficient secretion of antiviral cytokines including IFN- $\gamma$, and low proliferative capacity. Some factors contribute to this $\mathrm{CD}^{+} \mathrm{T}$ 

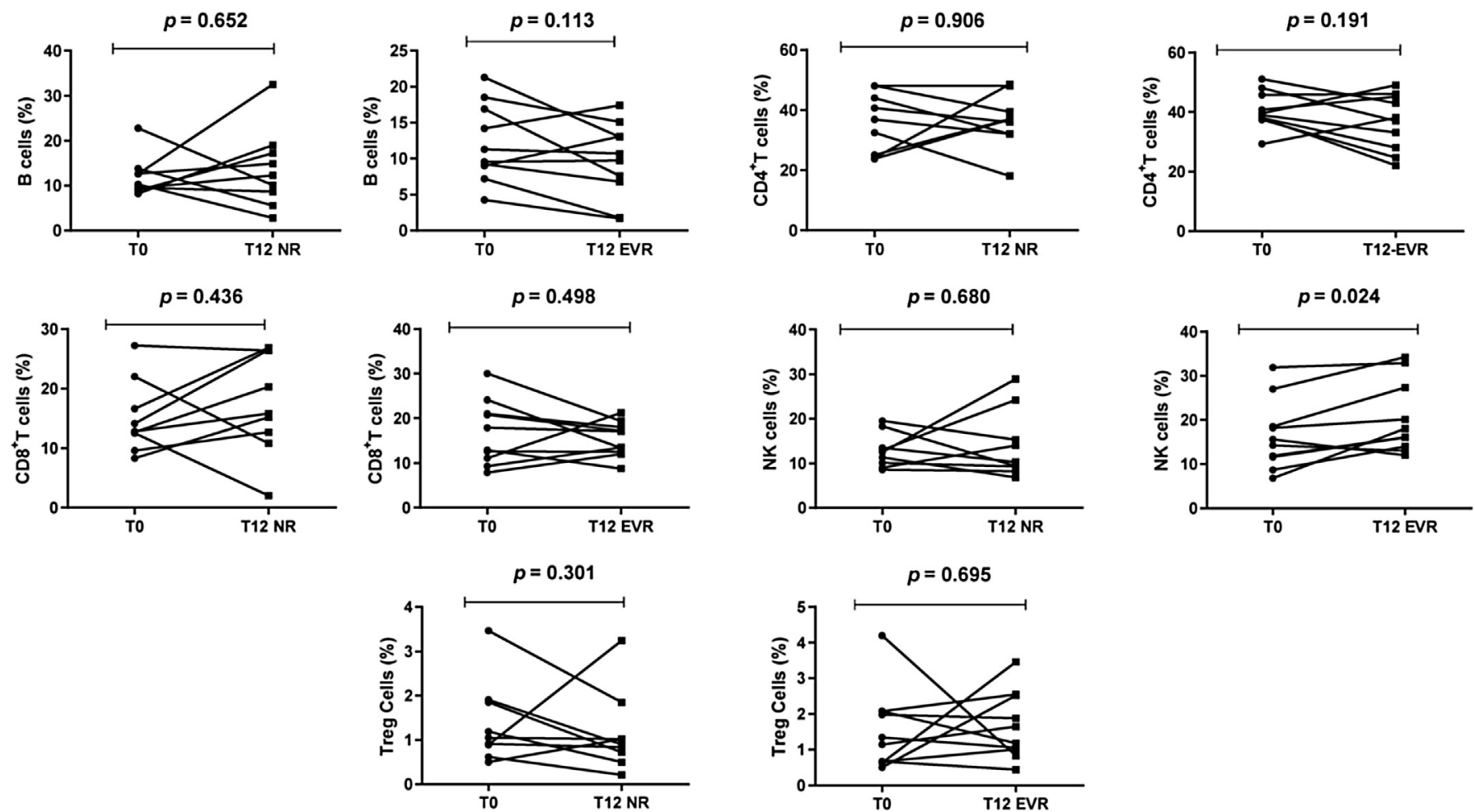

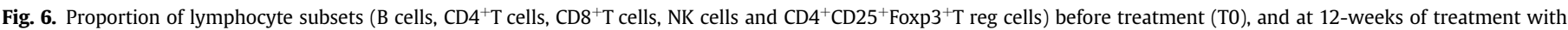
interferon- $\alpha$ plus ribavirin (T12). NR are nine treated patients that were non-responders and EVR are ten treated patients that achieved an early virologic response.

cell exhaustion in chronic HCV infection as high viral load, the down-regulation of $\mathrm{T}$ cell receptors, and the physical deletion of $\mathrm{HCV}$-specific $\mathrm{CD}^{+} \mathrm{T}$ cells $[34,35]$.

In conclusion, we demonstrated an altered profile of blood lymphocyte subsets in untreated HCV patients, including a reduction in the proportion of $\mathrm{CD} 4^{+} \mathrm{CD} 25^{+} \mathrm{FoxP} 3^{+} \mathrm{T}$ regulatory cells in untreated patients with cryoglobulinemia. An early virological response at 12 -weeks of treatment with IFN- $\alpha$ plus ribavirin is associated with a significant improvement in the proportion of NK cells.

\section{Conflict of interest}

The authors have no conflict of interest that is directly relevant to the content of this manuscript.

\section{Acknowledgments}

Research supported by the National Council for Scientific and Technological Development (CNPq, Grant No 475210/2010-7), L.P. Carvalho, R. Paraná, A.M. Atta, and M.L.B. Sousa Atta are recipients of CNPq-BPQ fellowships. I.S.Oliveira was a recipient of a CAPES scholarship.

\section{References}

[1] B. Hajarizadeh, J. Grebely, G.J. Dore, Epidemiology and natural history of HCV infection, Nat. Rev. Gastroenterol. Hepatol. 10 (9) (2013 Sep) 553-562.

[2] M.H. Lee, H.I. Yang, Y. Yuan, G. L'Italien, C.J. Chen, Epidemiology and natural history of hepatitis C virus infection, World J. Gastroenterol. 20 (28) (2014 Jul 28) 9270-9280

[3] C. Fauvelle, Q. Lepiller, D.J. Felmlee, I. Fofana, F. Habersetzer, F. Stoll-Keller, T.F. Baumert, S. Fafi-Kremer, Hepatitis $C$ virus vaccines-progress and perspectives, Microb. Pathog. 58 (2013 May) 66-72.

[4] L.B. Dustin, C.M. Rice, Flying under the radar: the immunobiology of hepatitis C, Annu. Rev. Immunol. 25 (2007) 71-99.
[5] H.R. Rosen, Clinical practice. Chronic hepatitis C infection, N. Engl. J. Med. 364 (25) (2011) 2429-2438.

[6] M. Spaan, H.L. Janssen, A. Boonstra, Immunology of hepatitis C virus infections, Best Pract. Res. Clin. Gastroenterol. 26 (4) (2012 Aug) 391-400.

[7] F. Ansaldi, A. Orsi, L. Sticchi, B. Bruzzone, G. Icardi, Hepatitis C virus in the new era: perspectives in epidemiology, prevention, diagnostics and predictors of response to therapy, World J. Gastroenterol. 20 (29) (2014 Aug 7) 9633-9652.

[8] A.L. Zignego, C. Ferri, S.A. Pileri, P. Caini, F.B. Bianchi, Italian association of the study of liver commission on extrahepatic manifestations of HCV infection. Extrahepatic manifestations of hepatitis $C$ virus infection: a general overview and guidelines for a clinical approach, Dig. Liver Dis. 39 (1) (2007 Jan) 2-17.

[9] D. Saadoun, D.A. Landau, L.H. Calabrese, P.P. Cacoub, Hepatitis C-associated mixed cryoglobulinaemia: a crossroad between autoimmunity and lymphoproliferation, Rheumatol. (Oxf.) 46 (8) (2007 Aug) 1234-1242.

[10] D. Vergani, G. Mieli-Vergani, Autoimmune manifestations in viral hepatitis Semin. Immunopathol. 35 (1) (2013 Jan) 73-85.

[11] O. Boyer, D. Saadoun, J. Abriol, M. Dodille, J.C. Piette, P. Cacoub, D. Klatzmann, $\mathrm{CD} 4^{+} \mathrm{CD} 25^{+}$regulatory $\mathrm{T}$-cell deficiency in patients with hepatitis C-mixed cryoglobulinemia vasculitis, Blood 103 (9) (2004 May 1) 3428-3430.

[12] D.A. Landau, M. Rosenzwajg, D. Saadoun, H. Trébeden-Negre, D. Klatzmann, P. Cacoub, Correlation of clinical and virologic responses to antiviral treatment and regulatory $\mathrm{T}$ cell evolution in patients with hepatitis $\mathrm{C}$ virus-induced mixed cryoglobulinemia vasculitis, Arthritis Rheum. 58 (9) (2008 Sep) 2897-2907.

[13] T. Boettler, H.C. Spangenberg, C. Neumann-Haefelin, E. Panther, S. Urbani, C. Ferrari, H.E. Blum, F. von Weizsäcker, R. Thimme, T cells with a CD4 $4^{+} \mathrm{CD} 25^{+}$ regulatory phenotype suppress in vitro proliferation of virus-specific $C D 8^{+} \mathrm{T}$ cells during chronic hepatitis C virus infection, J. Virol. 79 (12) (2005 Jun) $7860-7867$.

[14] R. Cabrera, Z. Tu, Y. Xu, R.J. Firpi, H.R. Rosen, C. Liu, D.R. Nelson, An immunomodulatory role for $\mathrm{CD} 4^{(+)} \mathrm{CD} 25^{(+)}$regulatory $\mathrm{T}$ lymphocytes in hepatitis $\mathrm{C}$ virus infection, Hepatology 40 (5) (2004 Nov) 1062-1071.

[15] A.M. Atta, P. Estevam, R. Paraná, C.M. Pereira, B.C. Leite, M.L. Sousa-Atta, Antiphospholipid antibodies in Brazilian hepatitis C virus carriers, Braz. J. Med. Biol. Res. 41 (6) (2008 Jun) 489-492.

[16] A.M. Atta, I.S. Oliveira, G.M. Sousa, R. Paraná, M.L. Atta, Serum cytokine profile in hepatitis $C$ virus carriers presenting cryoglobulinaemia and non-organspecific autoantibodies, Microb. Pathog. 48 (2) (2010 Feb) 53-56.

[17] G.M. Sousa, R.C. Oliveira, M.M. Pereira, R. Paraná, M.L. Sousa-Atta, A.M. Atta, Autoimmunity in hepatitis $C$ virus carriers: involvement of ferritin and prolactin, Autoimmun. Rev. 10 (4) (2011 Feb) 210-213.

[18] G.M. Sousa, I.S. Oliveira, L.J. Andrade, M.L. Sousa-Atta, R. Paraná, A.M. Atta, Serum levels of Th17 associated cytokines in chronic hepatitis C virus infection, Cytokine 60 (1) (2012 Oct) 138-142. 
[19] P. Bedossa, T. Poynard, An algorithm for the grading of activity in chronic hepatitis C. The METAVIR Cooperative Study Group, Hepatology 24 (2) (1996) 289-293.

[20] BRASIL. Ministério da Saúde, Protocolo Clínico e Diretrizes Terapêuticas para Hepatite Viral C e Coinfecções, Ministério da Saúde, Brasília, 2011.

[21] T. Okazaki, T. Nagai, T. Kanno, Gel diffusion procedure for the detection of cryoglobulins in serum, Clin. Chem. 44 (7) (1998 Jul) 1558-1559.

[22] D. Rosa, G. Saletti, E. De Gregorio, F. Zorat, C. Comar, U. D'Oro, S. Nuti, M. Houghton, V. Barnaba, G. Pozzato, S. Abrignani, Activation of naïve B lymphocytes via CD81, a pathogenetic mechanism for hepatitis C virusassociated B lymphocyte disorders, Proc. Natl. Acad. Sci. U. S. A. 102 (51) (2005 Dec 20) 18544-18549.

[23] E. Rosenthal, P. Cacoub, Extrahepatic manifestations in chronic hepatitis C virus carriers, Lupus 24 (4-5) (2015 Apr) 469-482.

[24] M. Fabris, L. Quartuccio, S. Sacco, G. De Marchi, G. Pozzato, C. Mazzaro, G. Ferraccioli, T.S. Migone, S. De Vita, B-Lymphocyte stimulator (BLyS) upregulation in mixed cryoglobulinaemia syndrome and hepatitis-C virus infection, Rheumatol. (Oxf.) 46 (1) (2007 Jan) 37-43.

[25] U.C. Meier, R.E. Owen, E. Taylor, A. Worth, N. Naoumov, C. Willberg, K. Tang, P. Newton, P. Pellegrino, I. Williams, P. Klenerman, P. Borrow, Shared alterations in NK cell frequency, phenotype, and function in chronic human immunodeficiency virus and hepatitis C virus infections, J. Virol. 79 (19) (2005 Oct) $12365-12374$.

[26] J. Corado, F. Toro, H. Rivera, N.E. Bianco, L. Deibis, J.B. De Sanctis, Impairment of natural killer (NK) cytotoxic activity in hepatitis C virus (HCV) infection, Clin. Exp. Immunol. 109 (3) (1997 Sep) 451-457.

[27] S. Lunemann, D.F. Malone, J. Hengst, K. Port, J. Grabowski, K. Deterding, A. Markova, B. Bremer, V. Schlaphoff, M. Cornberg, M.P. Manns, J.K. Sandberg, H.G. Ljunggren, N.K. Björkström, H. Wedemeyer, Compromised function of natural killer cells in acute and chronic viral hepatitis, J. Infect. Dis. 209 (9) (2014 May 1) 1362-1373.

[28] C.T. Tseng, G.R. Klimpel, Binding of the hepatitis C virus envelope protein E2 to CD81 inhibits natural killer cell functions, J. Exp. Med. 195 (1) (2002 Jan 7) 43-49.

[29] S. Crotta, A. Stilla, A. Wack, A. D'Andrea, S. Nuti, U. D'Oro, M. Mosca, F. Filliponi, R.M. Brunetto, F. Bonino, S. Abrignani, N.M. Valiante, Inhibition of natural killer cells through engagement of CD81 by the major hepatitis C virus envelope protein, J. Exp. Med. 195 (1) (2002 Jan 7) 35-41.

[30] G. Ahlenstiel, B. Edlich, L.J. Hogdal, Y. Rotman, M. Noureddin, J.J. Feld, L.E. Holz R.H. Titerence, T.J. Liang, B. Rehermann, Early changes in natural killer cell function indicate virologic response to interferon therapy for hepatitis C Gastroenterology 141 (4) (2011 Oct), 1231-9, 1239.e1-2.

[31] N. Semmo, G. Krashias, C. Willberg, P. Klenerman, Analysis of the relationship between cytokine secretion and proliferative capacity in hepatitis $C$ virus infection, J. Viral Hepat. 14 (7) (2007 Jul) 492-502.

[32] N. Semmo, C.L. Day, S.M. Ward, M. Lucas, G. Harcourt, A. Loughry, P. Klenerman, Preferential loss of IL-2-secreting CD4 $4^{+}$T helper cells in chronic HCV infection, Hepatology 41 (5) (2005 May) 1019-1028.

[33] N. Semmo, P. Klenerman, CD4 ${ }^{+}$T cell responses in hepatitis C virus infection, World J. Gastroenterol. 13 (36) (2007 Sep 28) 4831-4838.

[34] T. Lancaster, E. Sanders, J.M. Christie, C. Brooks, S. Green, W.M. Rosenberg, Quantitative and functional differences in $\mathrm{CD}^{+}$lymphocyte responses in resolved acute and chronic hepatitis C virus infection, J. Viral Hepat. 9 (1) (2002 Jan) 18-28.

[35] C. Neumann-Haefelin, H.C. Spangenberg, H.E. Blum, R. Thimme, Host and viral factors contributing to $\mathrm{CD}^{+} \mathrm{T}$ cell failure in hepatitis $\mathrm{C}$ virus infection, World J. Gastroenterol. 13 (36) (2007 Sep 28) 4839-4847. 